Prepared in cooperation with the City of Ithaca, New York, and the New York State Department of State

\title{
Bathymetric Survey and Estimation of Storage Capacity of Lower Sixmile Creek Reservoir, Ithaca, New York
}

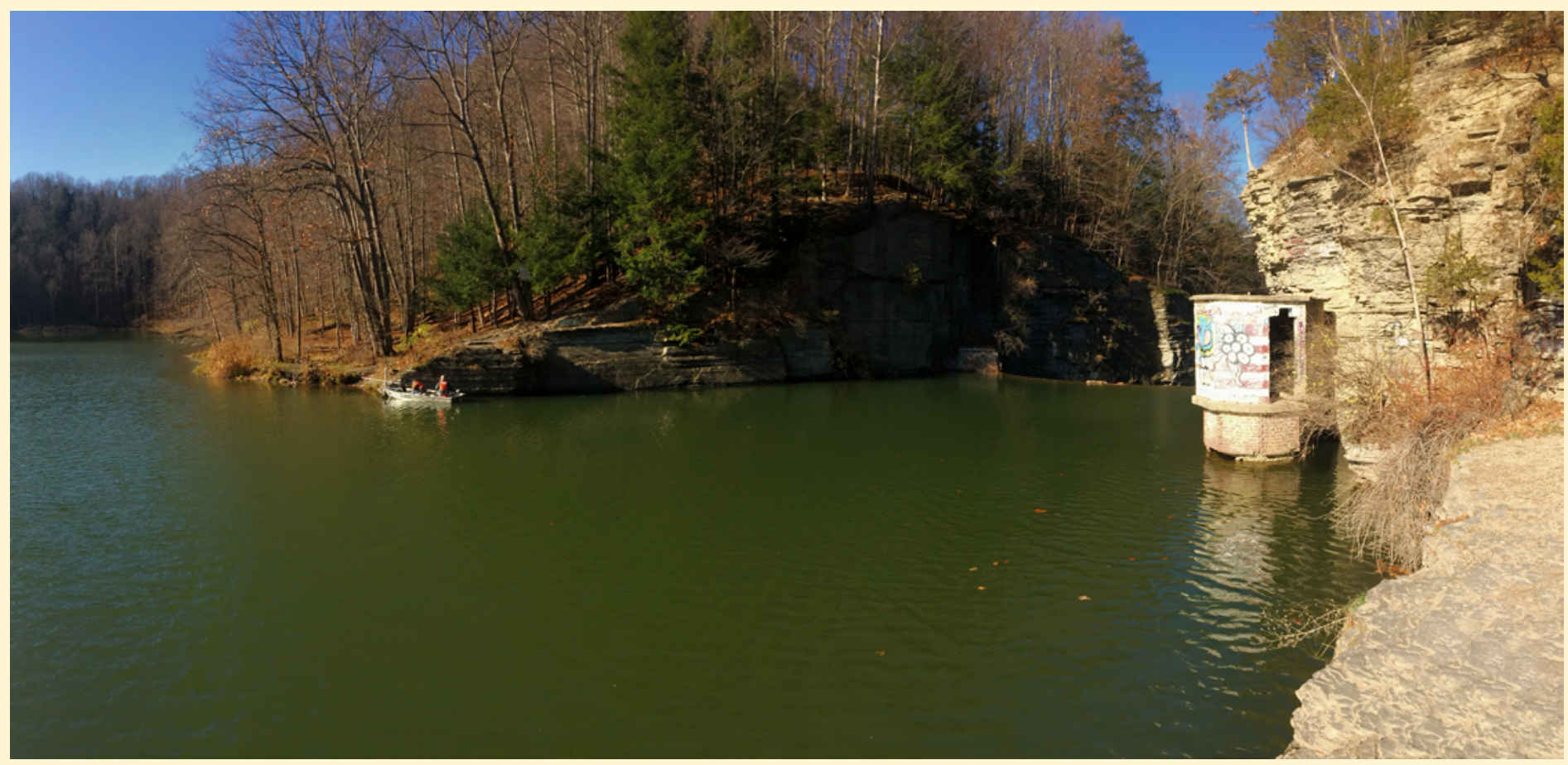

Open-File Report 2016-1157 
Cover. U.S. Geological Survey hydrographers conducting bathymetric survey of lower Sixmile Creek reservoir, Ithaca, New York. Crest of dam is between bedrock outcrops on right side of photograph. (Photograph by James Dye, U.S. Geological Survey.) 


\section{Bathymetric Survey and Estimation of Storage Capacity of Lower Sixmile Creek Reservoir, Ithaca, New York}

By John F. Wernly, Henry J. Zajd, Jr., and William F. Coon

Prepared in cooperation with the

City of Ithaca, New York, and the New York State Department of State

Open-File Report 2016-1157 


\title{
U.S. Department of the Interior SALLY JEWELL, Secretary
}

\section{U.S. Geological Survey Suzette M. Kimball, Director}

\author{
U.S. Geological Survey, Reston, Virginia: 2016
}

For more information on the USGS - the Federal source for science about the Earth, its natural and living resources, natural hazards, and the environment-visit http://www.usgs.gov or call 1-888-ASK-USGS.

For an overview of USGS information products, including maps, imagery, and publications, visit http://store.usgs.gov.

Any use of trade, firm, or product names is for descriptive purposes only and does not imply endorsement by the U.S. Government.

Although this information product, for the most part, is in the public domain, it also may contain copyrighted materials as noted in the text. Permission to reproduce copyrighted items must be secured from the copyright owner.

Suggested citation:

Wernly, J.F., Zajd, H.J., Jr., and Coon, W.F., 2016, Bathymetric survey and estimation of storage capacity of lower Sixmile Creek reservoir, Ithaca, New York: U.S. Geological Survey Open-File Report 2016-1157, 13 p., http://dx.doi.org/10.3133/ofr20161157.

ISSN 2331-1258 (online) 


\section{Acknowledgments}

This report was prepared with funding provided by the New York State Department of State under Title 11 of the Environmental Protection Fund. The authors would like to thank the personnel of the City of Ithaca, specifically Michael Thorne, superintendent for the Department of Public Works, and Erik Whitney, who assisted the U.S. Geological Survey in gaining access to the lower Sixmile Creek reservoir and transporting equipment into the Sixmile Creek gorge. The Geographic Information Systems (GIS) Program of the City of Ithaca, specifically Susan Nixson and Ruth Aslanis, created the bathymetric surfaces from 1938 and 2015 data that enabled calculation of the storage capacity of the reservoir. Scott Gibson, environmental engineer for the City of Ithaca, provided historical and other background information on the reservoir and its role in the water-supply system for the City of Ithaca.

Jared Marion and Nolan Milliman, both of the U.S. Geological Survey, assisted in the field and devised an extraction system for removal of the boat from the Sixmile Creek gorge at the end of the project. Thanks are extended to James Dye, of the U.S. Geological Survey, for his expertise in operating Global Positioning System (GPS) equipment, processing GPS data, and clarifying the presentation of GPS-related information in the report. The authors would also like to acknowledge the contributions of U.S. Geological Survey hydrologists Douglas Nagle and Benjamin Dietsch, who provided technical reviews of the report. 



\section{Contents}

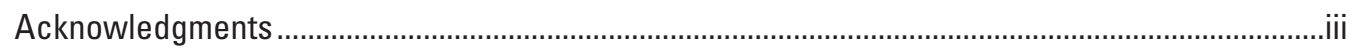

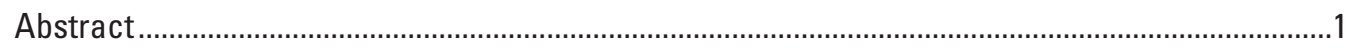

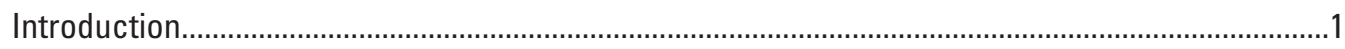

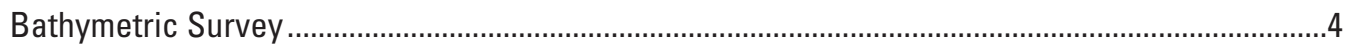

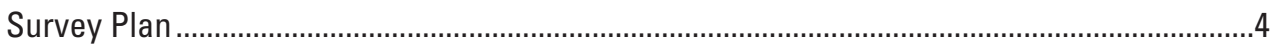

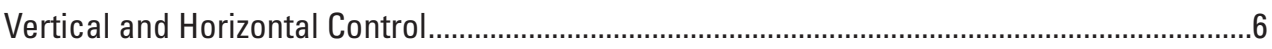

Postprocessing of Bathymetric Data ................................................................................

Vertical and Horizontal Control Accuracy .........................................................................

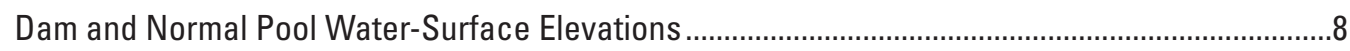

Creation of Bathymetric Surface ............................................................................................

Estimation of Surface Area and Storage Capacity ...................................................................

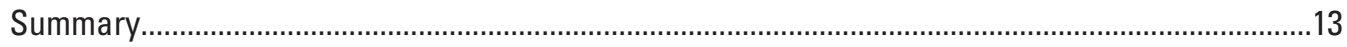

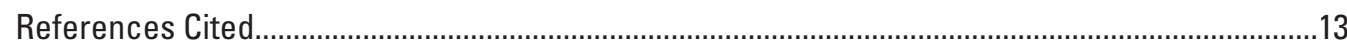

\section{Figures}

1. Map showing Sixmile Creek and locations of water-supply reservoirs in Ithaca, Tompkins County, New York ........................................................................................

2. Map showing the lower Sixmile Creek reservoir, including approximate 1938 reservoir boundary and 1949 landslide location, Ithaca, New York.................................3

3. Map showing locations of transects for echo-sounder depth measurements, target points for manual depth measurements, and shoreline target points from the bathymetric survey of the lower Sixmile Creek reservoir, Ithaca, New York ..............5

4. Map showing bathymetric surface of the lower Sixmile Creek reservoir, Ithaca,

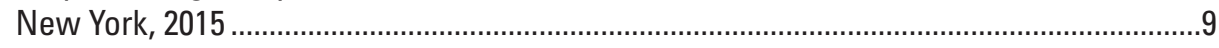

5. Map showing bathymetric surface of the lower Sixmile Creek reservoir, Ithaca,

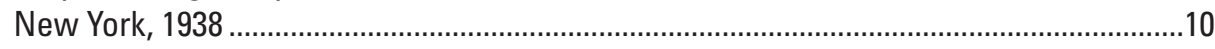

6. Graph showing surface area and storage capacity of the lower Sixmile Creek reservoir, Ithaca, New York, 1938 and 2015

\section{Table}

1. Surface area and storage capacity of the lower Sixmile Creek reservoir, Ithaca, New York, 1903, 1938, and 2015 ...... 


\section{Conversion Factors}

U.S. customary units to International System of Units

\begin{tabular}{lcl}
\hline & Multiply & \multicolumn{1}{c}{ Bo obtain } \\
\hline inch (in.) & Length & \\
inch (in.) & 2.54 & centimeter $(\mathrm{cm})$ \\
foot (ft) & 25.4 & millimeter $(\mathrm{mm})$ \\
mile (mi) & 0.3048 & meter $(\mathrm{m})$ \\
\hline & 1.609 & kilometer $(\mathrm{km})$ \\
\hline acre & Area & \\
acre & 4,047 & square meter $\left(\mathrm{m}^{2}\right)$ \\
\hline & 0.4047 & hectare $($ ha) \\
\hline acre-foot (acre-ft) & Volume & \\
\hline & 1,233 & cubic meter $\left(\mathrm{m}^{3}\right)$ \\
\hline foot per second $(\mathrm{ft} / \mathrm{s})$ & Flow rate & \\
foot per year $(\mathrm{ft} / \mathrm{yr})$ & 0.3048 & meter per second $(\mathrm{m} / \mathrm{s})$ \\
\hline
\end{tabular}

Temperature in degrees Celsius $\left({ }^{\circ} \mathrm{C}\right)$ may be converted to degrees Fahrenheit $\left({ }^{\circ} \mathrm{F}\right)$ as follows:

$$
{ }^{\circ} \mathrm{F}=\left(1.8 \times{ }^{\circ} \mathrm{C}\right)+32 .
$$

Temperature in degrees Fahrenheit $\left({ }^{\circ} \mathrm{F}\right)$ may be converted to degrees Celsius $\left({ }^{\circ} \mathrm{C}\right)$ as follows:

$$
{ }^{\circ} \mathrm{C}=\left({ }^{\circ} \mathrm{F}-32\right) / 1.8 \text {. }
$$

\section{Datum}

Vertical coordinate information is referenced to both the National Geodetic Vertical Datum of 1929 (NGVD 29) and the North American Vertical Datum of 1988 (NAVD 88).

Horizontal coordinate information is referenced to the North American Datum of 1983 (NAD 83).

Elevation, as used in this report, refers to distance above the vertical datum. 


\section{Abbreviations}

$\begin{array}{ll}\text { ADCP } & \text { acoustic Doppler current profiler } \\ \text { GIS } & \text { geographic information system } \\ \text { GPS } & \text { Global Positioning System } \\ \text { OPUS } & \text { National Geodetic Survey Online Positioning User Service } \\ \text { RMSE } & \text { root mean square error } \\ \text { RTK } & \text { real-time kinematic } \\ \text { TIN } & \text { triangular irregular network } \\ \text { USACE } & \text { U.S. Army Corps of Engineers } \\ \text { USGS } & \text { U.S. Geological Survey }\end{array}$





\title{
Bathymetric Survey and Estimation of Storage Capacity of Lower Sixmile Creek Reservoir, Ithaca, New York
}

\author{
By John F. Wernly, Henry J. Zajd, Jr., and William F. Coon
}

\section{Abstract}

During 2015, the U.S. Geological Survey, in cooperation with the City of Ithaca, New York, and the New York State Department of State, conducted a bathymetric survey of the lower Sixmile Creek reservoir in Tompkins County, New York. A former water-supply reservoir for the City of Ithaca, the reservoir is no longer a functional component of Ithaca's water-supply system, having been replaced by a larger reservoir less than a mile upstream in 1911. Excessive sedimentation has substantially reduced the reservoir's waterstorage capacity and made the discharge gate at the base of the 30-foot dam, which creates the reservoir, inoperable. U.S. Geological Survey personnel collected bathymetric data by using an acoustic Doppler current profiler. Across more than half of the approximately 14-acre reservoir, depths were manually measured because of interference from aquatic vegetation with the acoustic Doppler current profiler. City of Ithaca personnel created a bottom-elevation surface from these depth data. A second surface was created from depths that were manually measured by City of Ithaca personnel during 1938. Surface areas and storage capacities were computed at 1-foot increments of elevation for both bathymetric surveys. The results indicate that the current storage capacity of the reservoir at its normal water-surface elevation is about 84 acre-feet and that sediment accumulated between 1938 and 2015 has decreased the reservoir's capacity by about 68 acrefeet. This sediment load is attributed to annual inputs from the watershed above the reservoir, as well as from an episodic landslide that filled a large part of the reservoir along its northern edge in 1949.

\section{Introduction}

Since 1903, water-supply needs for the City of Ithaca in Tompkins County, New York, have been wholly or partly met by water impounded in one of two reservoirs on Sixmile Creek (fig. 1). Several bedrock constrictions along the length of the Sixmile Creek gorge made construction of the reservoirs technically feasible. The lower reservoir, completed in 1903, was formed by a 30 -foot (ft) dam and is officially named the Sixmile Creek Reservoir (New York State Department of Environmental Conservation, 2016), but it is locally referred to as the 30-foot-dam reservoir. The upper reservoir, completed in 1911, was formed by the 60 -foot-high Potters Falls Dam, and is officially and locally referred to as the Potters Falls Reservoir (Scott Gibson and Matthew Sledjeski, City of Ithaca Water and Sewer Division, written commun., 2015). However, on the U.S. Geological Survey (USGS) topographic map for "Ithaca, East" (U.S. Geological Survey, 2013), this upstream reservoir is identified as Ithaca Reservoir. To avoid confusion, herein these reservoirs will be referred to as the lower and upper Sixmile Creek reservoirs, respectively.

The lower reservoir covers about 14 acres and was relegated to a backup, emergency water supply when the upper reservoir was completed in 1911. Until 1959, the lower reservoir was used for water supply infrequently and only when operational problems or maintenance requirements interrupted water supply from the upper reservoir (U.S. Army Corps of Engineers, 1981). Presently (2016) the upper reservoir is the only operational reservoir of the two; excessive sedimentation in the lower reservoir has rendered both the valve to the water main in the control tower and the discharge gate at the base of the reservoir nonfunctional (Scott Gibson, City of Ithaca Water and Sewer Division, written commun., 2015). Sedimentation of the lower reservoir was a centurylong process of deposition of fine-grained sediment that was carried into the reservoir from the Sixmile Creek watershed; however, much of this infilling might have occurred prior to construction of the upper reservoir in 1911 and from a landslide that filled a large part of the reservoir along its northern edge, presumably during 1949 (Susan Nixson, City of Ithaca Geographic Information System [GIS] Program, written commun., 2015; fig. 2).

The USGS provides reliable scientific information to describe hydrologic systems and assists in understanding how hydrologic and geomorphic conditions can change over time. In most instances, this involves documenting and analyzing the effects of widely recognized phenomena, such as surface-water and groundwater flow and quality. On occasion, this involves relatively small-scope studies of previously unrecognized phenomena, such as reservoir sedimentation and (or) landslides that emerge as natural hazards. The USGS works within its strategic science 


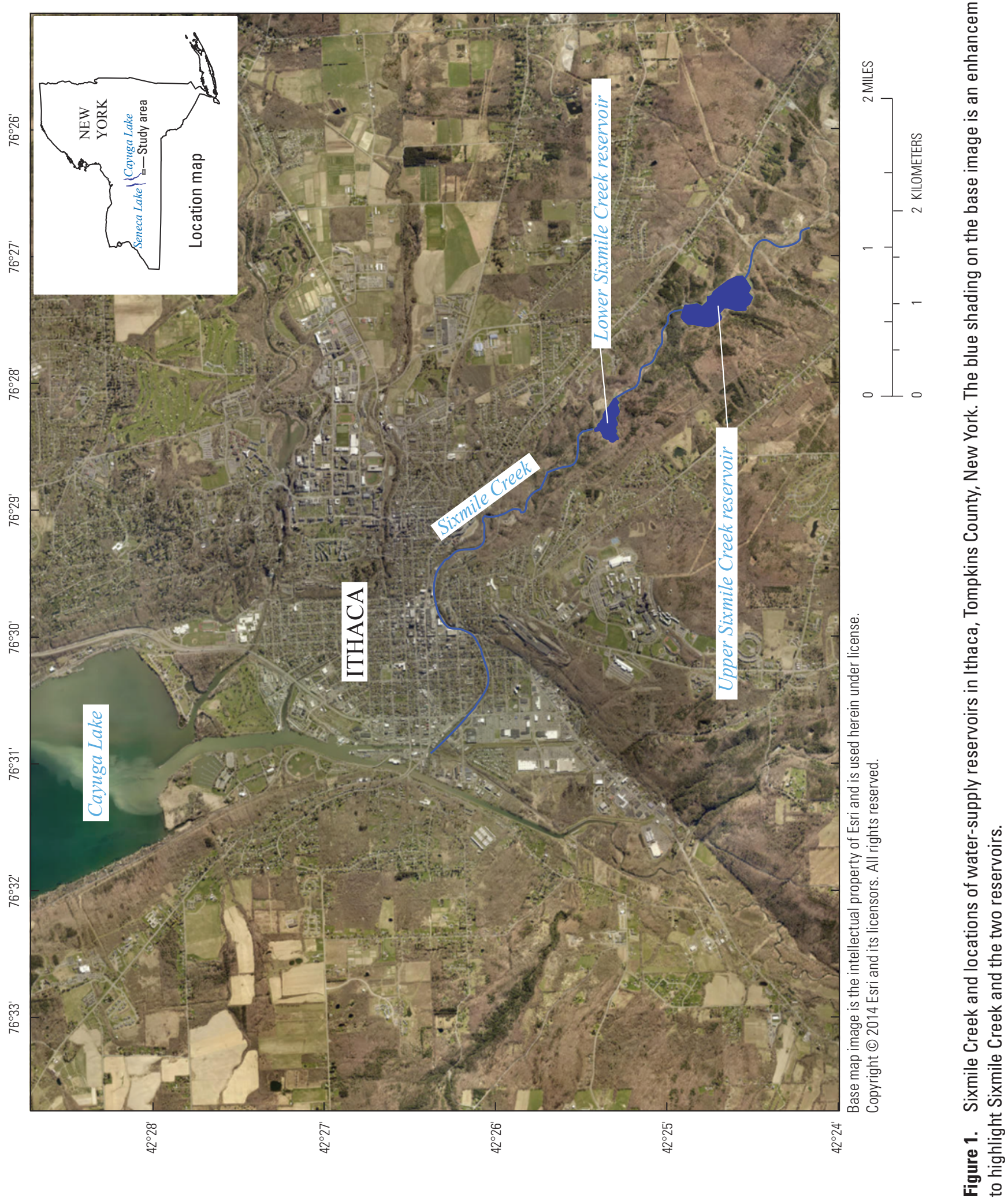




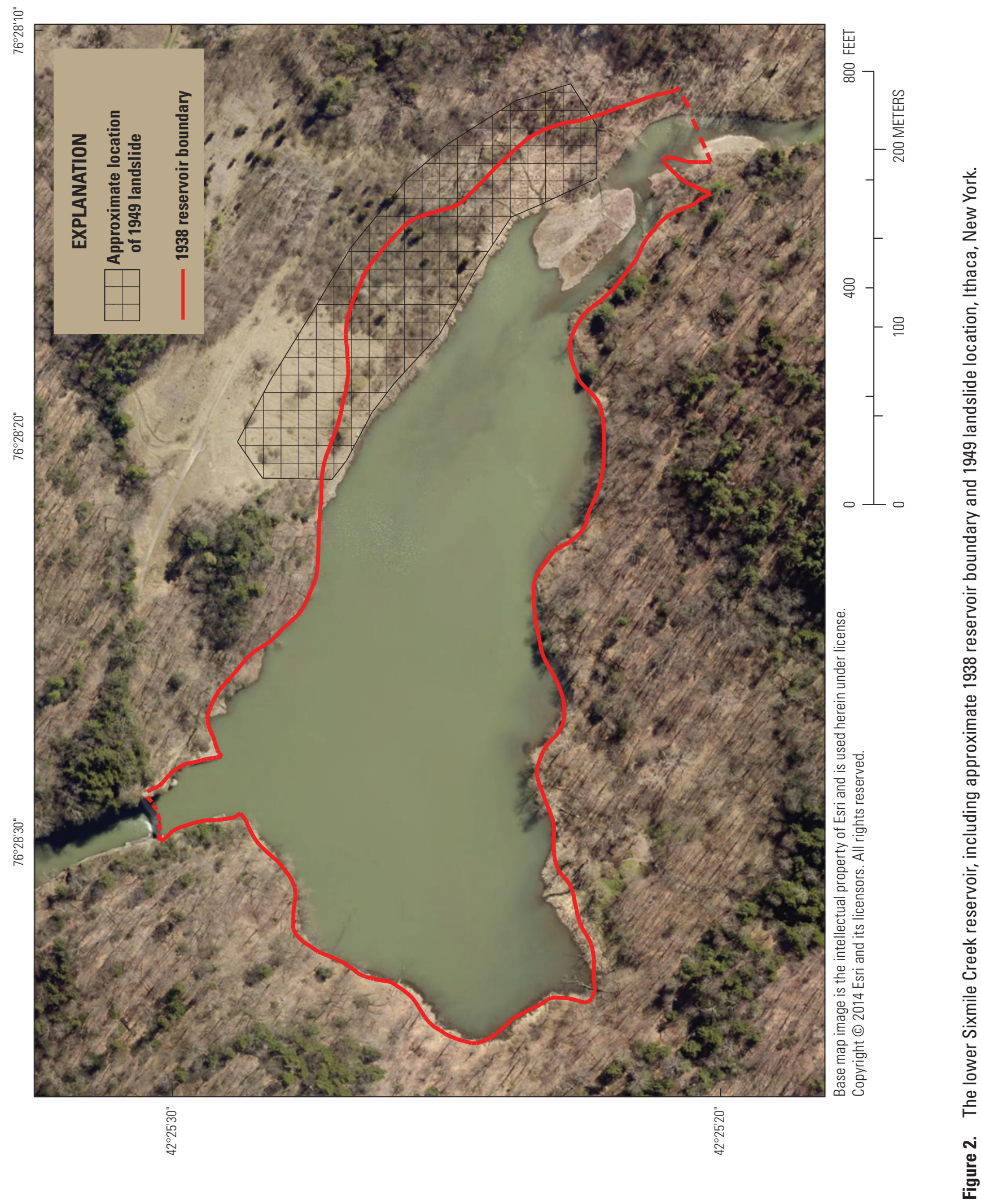


Bathymetric Survey and Estimation of Storage Capacity of Lower Sixmile Creek Reservoir, Ithaca, New York

direction and with its cooperative partners, such as the City of Ithaca, to document emerging environmental conditions and (or) hazards and to ensure that scientific methods are applied effectively to better understand these phenomena and thereby inform environmental managers on water resources and associated infrastructure.

In 2015, the USGS, in cooperation with the City of Ithaca and the New York State Department of State, conducted a bathymetric survey of the lower Sixmile Creek reservoir. Data from this survey were used to estimate the volume of sediment that has accumulated and the current water-storage capacity of the reservoir. These results could be of use to City of Ithaca personnel faced with a management decision regarding the disposition of the $30-\mathrm{ft}$ dam. Options being considered include demolition and removal of the dam, renovation of the dam to meet current New York State safety standards, and repair of the gate at the base of the dam to permit use of the reservoir for flood-control purposes.

The purpose of this report is to document the procedures followed during collection of bathymetric data from the lower Sixmile Creek reservoir and to present estimates of the water-storage capacity and volume of accumulated sediment in the reservoir. The report describes the collection of depth data along transects and at target points, the processing of the depth data, and the assessment of the accuracy of the depth measurements. These data are available as a separate data release through USGS ScienceBase (Wernly and others, 2016). The report explains how the reference elevation was determined for calculation of the reservoir's storage capacity. Two maps of the bathymetric surface of the reservoir, created by City of Ithaca personnel, are presented: one from depth data collected in this study and one from data collected in a 1938 survey. The report describes the computation of the water-storage capacity of the reservoir and the comparison of the results with similar data produced from the 1938 survey. On the basis of these results, the volume of accumulated sediment in the reservoir is estimated.

\section{Bathymetric Survey}

Bathymetric data were collected with an acoustic Doppler current profiler (ADCP), specifically a SonTek RiverSurveyor M9 with a 0.5-megahertz integral verticalbeam echo sounder (SonTek, 2015b). An echo sounder measures water depths by measuring the time interval required for ultrasonic waves to travel, at a known velocity, from a known point (transducer face) to a reflecting surface (reservoir bottom) and then return. A minimum depth limitation applies when the reflecting surface is too close to the echosounder face (generally less than about $1.5 \mathrm{ft}$ for this survey) or if aquatic vegetation interferes with the echo-sounder transmission. In these cases, depths were manually sensed with a fiberglass stadia rod incremented in tenths of a foot.
A 6-inch steel circular pad, affixed to the bottom of the rod, minimized settling of the rod below the top of the soft bottom.

The velocity of sound in water is dependent upon the salinity, temperature, and depth. The salinity and relatively shallow depths typically encountered in freshwater lakes are not major factors that affect the sound velocity (U.S. Army Corps of Engineers, 2002). ADCPs have built-in temperature sensors that measure water temperature at the transducer face and permit the computation of the sound velocity and the subsequent accurate measurement of depth. To confirm the accuracy of the ADCP's sound-velocity calculation, surfacewater temperature was measured independently by means of a thermistor. Throughout the survey the ADCP temperature sensor varied by no more than 0.2 degrees Celsius from the independently measured surface-water temperatures, and water temperatures recorded at depths of 5 and $10 \mathrm{ft}$ varied by no more than 0.1 degrees Celsius from the measured surface temperature. Therefore, no variation in sound velocity with depth, as a function of change in temperature, was expected in this shallow reservoir.

Before surveying each day, the depth readings of the echo sounder were checked by means of a bar check to ensure accurate depth sounding. A plate was suspended at known depths -5 and $10 \mathrm{ft}$ - below the transducer face. The depth indicated by the echo-sounder signal that was reflected off the submerged plate was compared with the known depth of the plate. As an additional check, manual depth measurements were made periodically along the surveyed transects and were compared with echo-sounder-measured depths.

All data were referenced to the horizontal datum, North American Datum of 1983, and vertical datum, North American Vertical Datum of 1988 (NAVD 88). The survey was conducted from November 16 to 20, 2015.

\section{Survey Plan}

Guidelines for conducting a bathymetric survey as described by Wilson and Richards (2006) were followed. The first set of planned survey transects was arranged perpendicular to the gorge section where the dam is located (fig. 3). Given the relatively short length of the reservoir (approximately 1,400 ft), the minimum transect interval of $30 \mathrm{ft}$ was selected. Closer spacing was deemed infeasible because of the impracticality of maintaining boat position along planned transects that were spaced more closely than $30 \mathrm{ft}$ (Wilson and Richards, 2006).

Site reconnaissance indicated that over half of the reservoir - the upstream part-had shallow depths and that its bottom was covered by dense aquatic vegetation, which interfered with the use of the ADCP and required manual measurement of depths. Therefore, a second set of transects was created for measuring manually sensed depths. This set was oriented similarly to the 30 -ft transects, but the spacing was increased to $50 \mathrm{ft}$. Target points, which served as markers for manually measured depths, were created along these 


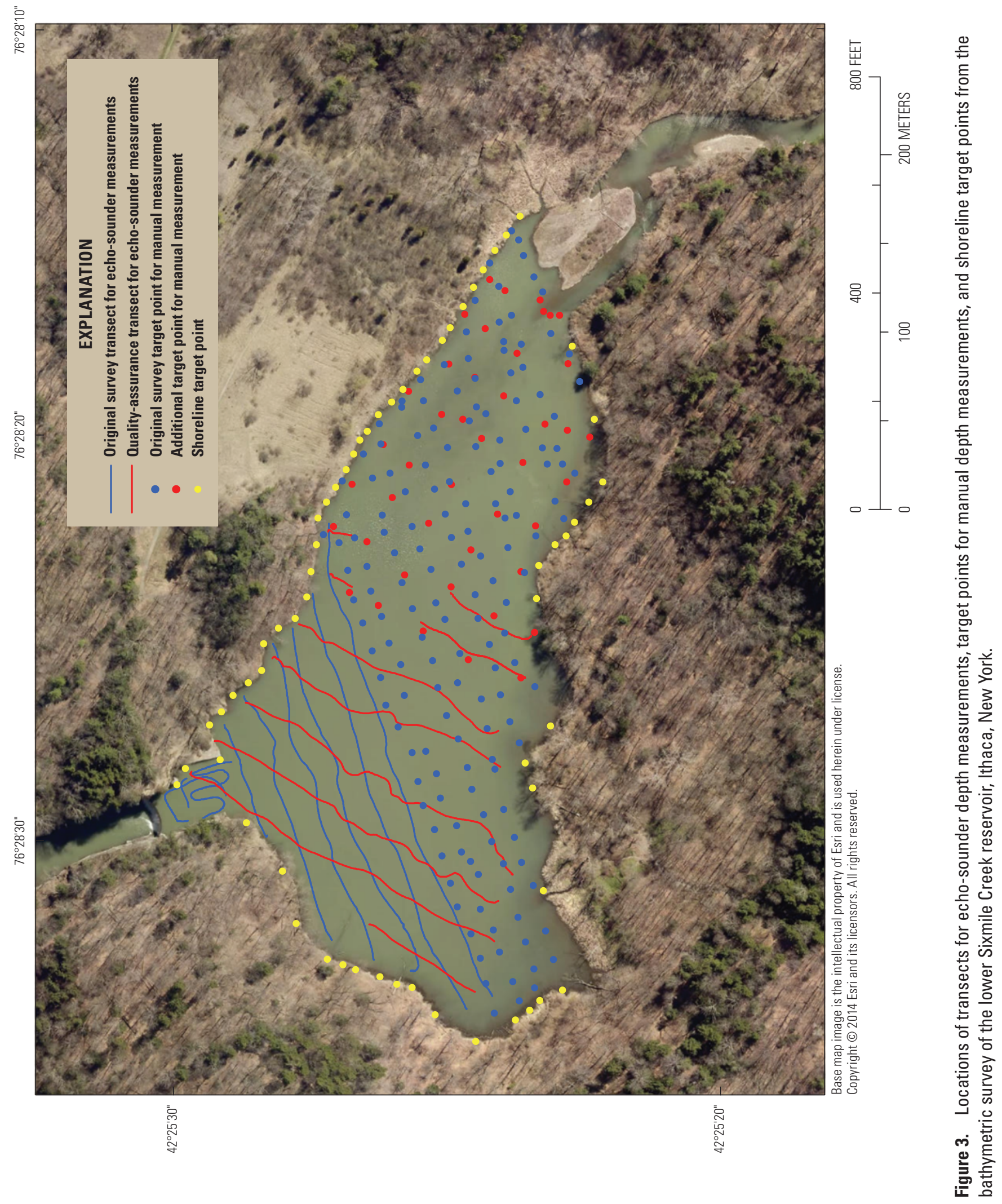


transects at 50-ft intervals (fig. 3). Spacing was increased because of labor and time constraints and was justified on the basis of the gradual change in depths from point to point across the reservoir.

For quality assurance, a third set of transects was created to provide an independent dataset with which the vertical accuracies of the ADCP data could be assessed (fig. 3). These transects were oriented 45 degrees to the original transects and were spaced $90 \mathrm{ft}$ apart, three times as far apart as the original transects. Included in this dataset, but not used for qualityassurance purposes, were manually measured target points along transects that were spaced every $50 \mathrm{ft}$ in the part of the reservoir where vegetation interfered with the ADCP. These additional target points were added to the original dataset from this part of the reservoir to increase the data density for creation of the bathymetric surface.

A final dataset of target points was collected along the shoreline of the reservoir to provide an areal boundary for the surveyed data (fig. 3). These shoreline points were collected at the end of each 30-ft planned transect. Collection was performed by placing the ADCP with its real-time kinematic (RTK) Global Positioning System (GPS) on the bow of the boat and driving the boat, bow-first, to the edge of water. When the bow was at the shoreline edge, horizontal coordinates were recorded while a depth of zero was assigned.

HYPACK software (HYPACK, Inc., 2015) was used to create the transects and the target points over the length of the reservoir and thus enabled the collection of consistently spaced water depths. A georeferenced aerial image of the reservoir was used within HYPACK, both for office planning of transects and for guidance of the survey team in the field. The survey team used an onboard differential GPS (separate from the ADCP's RTK GPS) that was coupled to a computer, on which HYPACK was running, to navigate the transects in real time and keep track of their data-collection progress.

\section{Vertical and Horizontal Control}

A vertical control point was established on a bedrock ledge about $140 \mathrm{ft}$ upstream from the dam and near the edge of water. A survey-grade dual-frequency GPS receiver (Trimble, 2016), operated in a static RTK and logging datacollection mode, recorded GPS data once per second during a 4-hour observation session. These GPS data were submitted to the National Geodetic Survey Online Positioning User Service (OPUS; National Geodetic Survey, 2015) to obtain the positional coordinates of the control point. The elevation and coordinates of this point, which are an average of three independent single-baseline solutions, were determined to have a vertical accuracy of $0.046 \mathrm{ft}$ and a horizontal accuracy of $0.026 \mathrm{ft}$, respectively. These accuracy values are peakto-peak errors as reported in the OPUS solution report and represent the difference between the maximum and minimum values of the coordinates obtained from the three baseline solutions (Rydlund and Densmore, 2012). The elevation of the control point was referenced to NAVD 88 (using the geoid model GEOID12B). The control point was used as a reference point from which the water-surface elevation of the reservoir was measured by tape-down with a weighted steel tape. Such measurements were made at the beginning and end of each survey workday. During postprocessing of the data, water depths (adjusted for the transducer depth) were subtracted from these water-surface elevations to obtain reservoir-bottom elevations.

Horizontal survey positions for the ADCP and manually sensed data were acquired through the use of a RTK-GPS receiver positioned directly above the ADCP where depths were measured. This unit received horizontallocation corrections from an onshore RTK base station, which was within line of sight of the survey vessel and provided a manufacturer-stated horizontal survey accuracy of 3 centimeters $(\mathrm{cm})$ or $0.10 \mathrm{ft}$ relative to the base station. The software associated with the RiverSurveyor M9 ADCP, RiverSurveyor LIVE (version 3.8; SonTek, 2015a), does not allow input of a control-point location for the base station, nor does it allow for the logging of observations that could be postprocessed in OPUS. RiverSurveyor LIVE is designed for measuring streamflow where the absolute georeferenced location of the ADCP is not critical to a precision of $\pm 3 \mathrm{~cm}$. The system uses the base station to correct the ADCP position to $\pm 3 \mathrm{~cm}$ relative to itself for the purpose of accurately measuring stream width to calculate discharge. This system was adapted for our bathymetric use by obtaining a high level of accuracy for the ADCP relative to the position of the RTK base station, whereas, without the ability to enter a controlpoint location for the RTK base station, the absolute position of the ADCP may only have attained submeter accuracy.

Latency is the time difference or lag between the time when positioning data are received and the time when the computed or processed position reaches the data logging module and is time tagged. Latency typically results in a negative along-track spatial displacement of the depth value. This displacement can be minimized by surveying at slow speeds and by synchronizing the echo-sounder and GPS clocks. Boat speed was kept at a minimum throughout the survey. Boat speed averaged 0.90 feet per second ( $\mathrm{ft} / \mathrm{s}$ ) during the planned transects and $1.60 \mathrm{ft} / \mathrm{s}$ during the quality-assurance transects. The RiverSurveyor M9 ADCP minimizes latency through the use of the integrated RTK-GPS located above the ADCP, which directly connects the incoming GPS data stream to the ADCP. Unlike other echo-sounder systems, the RiverSurveyor M9 ADCP performs internal calculations with the GPS data, synchronized by the system with a 10-hertz update rate, before the data are stored in the computer. Latency was not quantified, but it was considered small enough, given the slow survey speed and integrated GPS, that any potential errors in the data were negligible for this survey. 


\section{Postprocessing of Bathymetric Data}

Reservoir water-surface elevations were measured twice daily from the surveyed reference point. More frequent measurements were unnecessary given the base-flow conditions that existed during the survey period. Water-surface elevations varied by $0.02 \mathrm{ft}$ or less during a given day and by only $0.07 \mathrm{ft}$ over the course of the survey. Reservoir-bottom elevations were computed by subtracting the measured depths, which included an adjustment for the transducer depth, from the mean water-surface elevation for a given day. The resultant data were processed by using ArcGIS (version 10.3.1), which contains hydrographic software for data viewing and editing, data processing, generation of interpolated data, and creation of map products (Esri, 2015). Raw transect data were reviewed in RiverSurveyor LIVE, the software associated with the RiverSurveyor M9 ADCP (SonTek, 2015a), for erroneous measurements that could result from false reflections from fish, trees, and other submerged objects. In addition, those data that did not meet RTK quality, as sometimes occurred when the GPS signal was lost near the steep walls of the gorge and the upstream face of the dam, were also identified. These data were removed, and the remaining transect data were saved as edited transects.

\section{Vertical and Horizontal Control Accuracy}

The vertical-beam echo sounder used in this study has a resolution of 1 millimeter $(0.003 \mathrm{ft})$ and an accuracy of 1 percent of the measured depth, according to the manufacturer's specifications (SonTek, 2015b). An assessment of the vertical accuracy of the measured depths and resultant reservoir-bed elevations was possible by comparing results for coincident points measured in the original set of transects (30-ft spacing) and the quality-assurance set of transects (90-ft spacing). Sixty paired intersection points were found for comparison. The horizontal distances between the paired points averaged $0.48 \mathrm{ft}$ and ranged from 0.07 to $1.05 \mathrm{ft}$. The absolute differences in elevations ranged from 0 to $0.69 \mathrm{ft}$; the median absolute difference was $0.10 \mathrm{ft}$. The vertical root mean square error (RMSE) and the vertical accuracy of the elevations at the 95-percent confidence level were computed by using the following equations:

$$
R M S E_{z}=\sqrt{\frac{\sum_{i=1}^{n}\left(\text { Zorig }_{i}-Z q a_{i}\right)^{2}}{n}},
$$

where

$$
\begin{aligned}
& R M S E_{z} \quad \text { is the vertical root mean square error, } \\
& \text { Zorig }_{i} \text { is the vertical coordinate of the } i \text { th check point } \\
& \text { in the original dataset, } \\
& Z q a_{i} \quad \text { is the vertical coordinate of the } i \text { th check point } \\
& \text { in the quality-assurance dataset, }
\end{aligned}
$$

$i \quad$ is an integer from 1 to $n$, and

$n \quad$ is the number of points being checked.

$$
A_{z}=1.960 \times R M S E_{\mathrm{z}},
$$

where

$$
\begin{gathered}
A_{z} \quad \text { is the vertical accuracy calculated at the } \\
\text { 95-percent confidence level. }
\end{gathered}
$$

The RMSE of the ADCP-collected elevation data was $0.25 \mathrm{ft}$, and the vertical accuracy was $0.49 \mathrm{ft}$ at the 95 -percent confidence level.

Echo-sounder-measured depths were also assessed by comparison with manual depth measurements. After controlling for erroneous echo-sounder depths affected by aquatic vegetation, a total of 56 points throughout the reservoir were found for comparison. Measured depths ranged from 1.28 to $11.4 \mathrm{ft}$, with differences between manual and echo-sounder measurements ranging from -0.10 to $0.81 \mathrm{ft}$. The median absolute difference between manually measured depths and those measured with the echo sounder was $0.14 \mathrm{ft}$. Accuracy of these comparisons was affected by boat drift and aquatic vegetation. Boat drift introduced uncertainty in the comparisons owing to an inability to measure the exact same point with the stadia rod as that measured by the echo sounder. The maximum difference in depths was measured in an area of rapidly changing elevation and likely reflects this source of inaccuracy. Echo-sounder depths which were known to have been affected by aquatic vegetation from field notes and a visual analysis of the data were removed from the comparison. However, it is possible that some depth measurements that were affected by aquatic vegetation were retained in the comparison. The average depth difference of $+0.16 \mathrm{ft}$ (manual depth minus the echo-sounder depth) indicates that the echo sounder measured less depth, and this result could, at least partly, be due to unseen aquatic vegetation interfering with the echo-sounder transmissions. Evidence for this potential source of error was the presence of aquatic vegetation sometimes found clinging to the bottom of the stadia rod when it was returned to the boat. A second plausible contributor to this apparent bias in echo-sounder depth measurements could be the settling of the stadia rod into the soft substrate, despite the attachment of a 6-inch pad to the bottom of the rod to minimize this problem. The vertical accuracy of depths manually measured with the stadia rod was not evaluated as part of this study, but is assumed to be comparable to the computed accuracy of the echo-sounder measurements.

The horizontal positional accuracy of the RTK-GPS receiver in the ADCP is $3 \mathrm{~cm}(0.01 \mathrm{ft})$, according to the manufacturer (SonTek, 2015b). However, horizontal accuracy is affected by the multipath environment (that is, proximity to trees, buildings, cliffs, and so on), the number of satellites in view, satellite geometry, and ionospheric activity. No independent testing was conducted to confirm the stated horizontal accuracy of the reservoir survey, but for the purposes of this study, the exact location of a given surveyed 
point in space was deemed to be less important than the relative locations among the surveyed points and the distances between adjacent points. Therefore, the manufacturer's level of accuracy was accepted as stated.

\section{Dam and Normal Pool Water-Surface Elevations}

Before discussion of the creation of a bathymetric surface from the measured depths and calculation of the storage capacity of the reservoir, the issue of the reference elevation of the reservoir's normal pool should be clarified. The normalpool water-surface elevation is defined as the elevation of the ponded water under base-flow conditions and is determined by the crest of the dam. Substantial discrepancies exist in regards to the crest elevation of the $30-\mathrm{ft}$ dam at the lower Sixmile Creek reservoir. (Unless otherwise noted, the following cited elevations are referenced to the National Geodetic Vertical Datum of 1929 [NGVD 29].) The City of Ithaca has historically used $583.5 \mathrm{ft}$ for the crest elevation (Scott Gibson, City of Ithaca Water and Sewer Division, written commun., 2015). However, a 1938 survey map of the reservoir indicates a crest elevation of $584 \mathrm{ft}$ (Susan Nixson, City of Ithaca GIS Program, written commun., 2015), and a recent engineering assessment of the $30-\mathrm{ft}$ dam by C.T. Male Associates (2014) gives the crest elevation as $585 \mathrm{ft}$. Two other separate sources concur in an elevation of $583 \mathrm{ft}$. A U.S. Army Corps of Engineers (USACE; 1981, p. 3) dam-inspection report cites the original as-built crest elevation of $201 \mathrm{ft}$ (local datum) that was "approximately equal to USGS mean sea level minus 382 " (or 583 minus $382=201 \mathrm{ft}$ ). This means that the USACE value started with a crest elevation of $583 \mathrm{ft}$. In addition, the USGS "Ithaca, East" topographic map (U.S. Geological Survey, 2013) gives $583 \mathrm{ft}$ as the reservoir's mean watersurface elevation.

As mentioned previously, static GPS was used to obtain the elevation of a reference point from which the water-surface elevation was determined each day of the survey. The mean water-surface elevation under base-flow conditions (that is, the normal pool) was $582.5 \mathrm{ft}$, referenced to the North American Vertical Datum of 1988 (NAVD 88), or $583.0 \mathrm{ft}$, referenced to NGVD 29. (The conversion from NGVD 29 to NAVD 88, $-0.54 \mathrm{ft}$, was computed by using VERTCON [National Geodetic Survey, 2016]). The NGVD 29 value, which agrees with the USACE and USGS elevations of $583 \mathrm{ft}$, was used as the reference elevation for the subsequent calculation of the reservoir's storage capacity.

\section{Creation of Bathymetric Surface}

The bathymetric data that were collected by the USGS were used by personnel of the City of Ithaca GIS Program (Susan Nixson, written commun., 2015) to produce a triangular irregular network (TIN) of the bottom of the reservoir (fig. 4). The TIN was projected in a State plane (New York Central) coordinate system. These data are available as a separate data release through USGS ScienceBase (Wernly and others, 2016).

A similar TIN surface was created from data collected by City of Ithaca personnel during a 1938 survey of the reservoir (fig. 5). The outline of the reservoir in 1938 is shown in figure 2 for comparison with the present-day reservoir extent. At that time, manually sensed depths were measured in a fixed pattern across the reservoir. The reservoir's water-surface elevation in 1938 was unknown, but the crest elevation of the dam, which would have approximated the water-surface elevation, was noted as $584 \mathrm{ft}$. As discussed in the previous section, $583 \mathrm{ft}$ has been identified as the crest elevation of the dam. Therefore, although initial calculations of the reservoir's bottom elevations used $584 \mathrm{ft}$ as the reference elevation for converting depths to elevations, the computed storage data presented in the following section are based on a reference elevation of $583.0 \mathrm{ft}$, NGVD 29 (582.5 ft, NAVD 88). This adjustment brought the 1938 survey into agreement with the elevation of the reservoir's current normal pool and the water surface at the time of the USGS 2015 survey and thereby permitted direct comparison of reservoir storage capacities computed from the 2015 and 1938 datasets. The maps presented in figures 4 and 5 are available as a separate data release through USGS ScienceBase (Wernly and others, 2016).

\section{Estimation of Surface Area and Storage Capacity}

Presumably the maximum depth of the original reservoir was the height of the dam, $30 \mathrm{ft}$. The greatest depth noted on the bathymetric survey of 1938 was $20.0 \mathrm{ft}$, which was measured about $15 \mathrm{ft}$ upstream from the dam, near the water-supply outflow tower on the eastern gorge wall. This difference in depths indicates that by 1938, about $10 \mathrm{ft}$ of sediment had accumulated at the point of measurement upstream from the dam. The greatest depth measured in $2015,16.6 \mathrm{ft}$, was about $130 \mathrm{ft}$ upstream from the dam and also near the eastern gorge wall. These depths cannot be directly compared because they are from different points in the reservoir; however, shallower depths were recorded at about the same point just upstream from the dam during both surveys. A depth of $16.3 \mathrm{ft}$ was measured in 1938 about the same distance upstream from the dam as the maximumdepth measurement, but near the center of the channel. At a similar location in the channel in 2015, the measured depth was $13.5 \mathrm{ft}$. This comparison indicates that $16.5 \mathrm{ft}$ of sediment had accumulated at this point since the dam was constructed in 1903, but less than $3 \mathrm{ft}$ had accumulated since 1938. These data indicate that the rate of sedimentation was much greater prior to 1938 - about 0.39 foot per year (ft/yr) - than between 1938 and $2015-0.036 \mathrm{ft} / \mathrm{yr}$. If annual depth measurements 


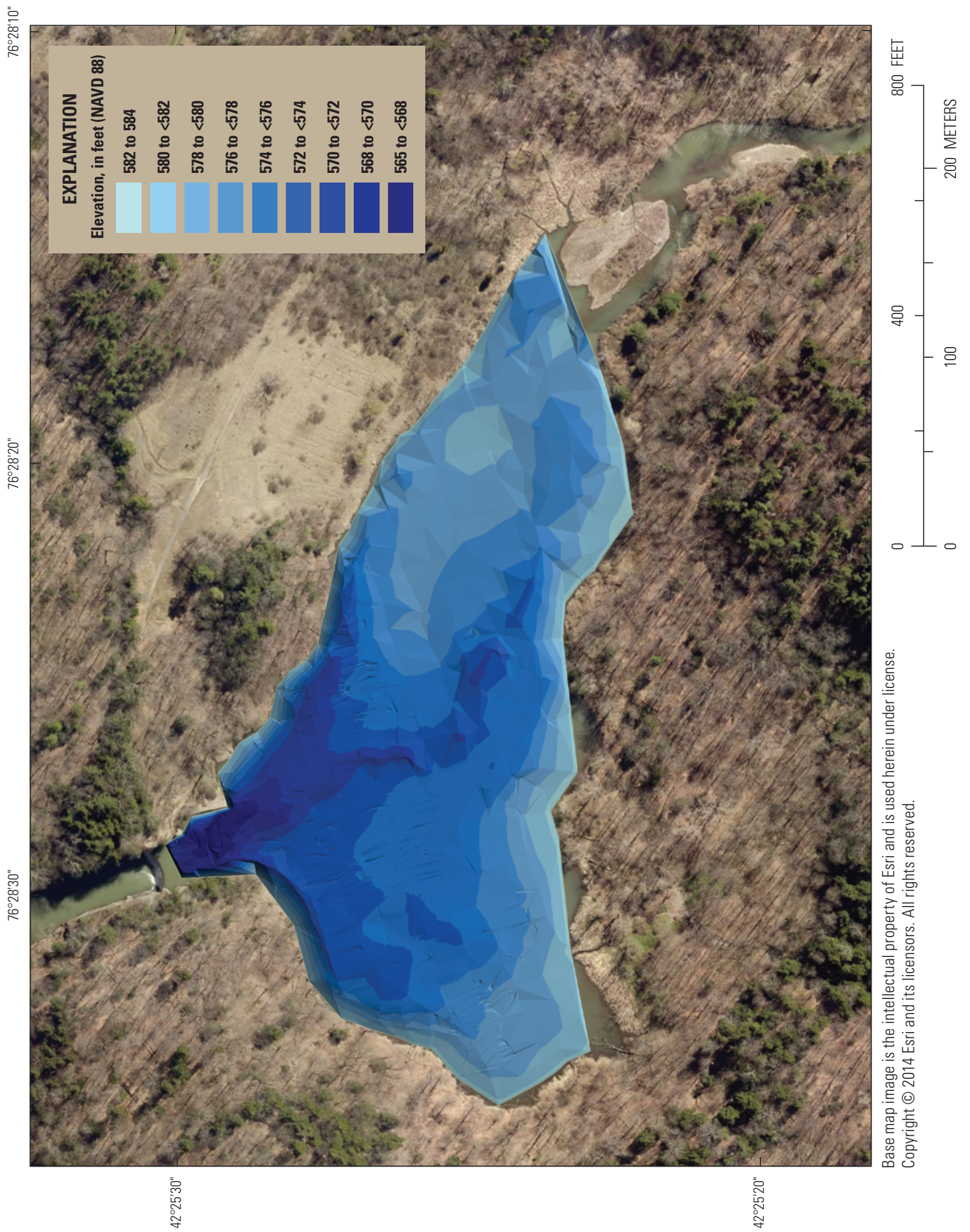

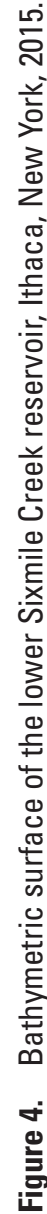




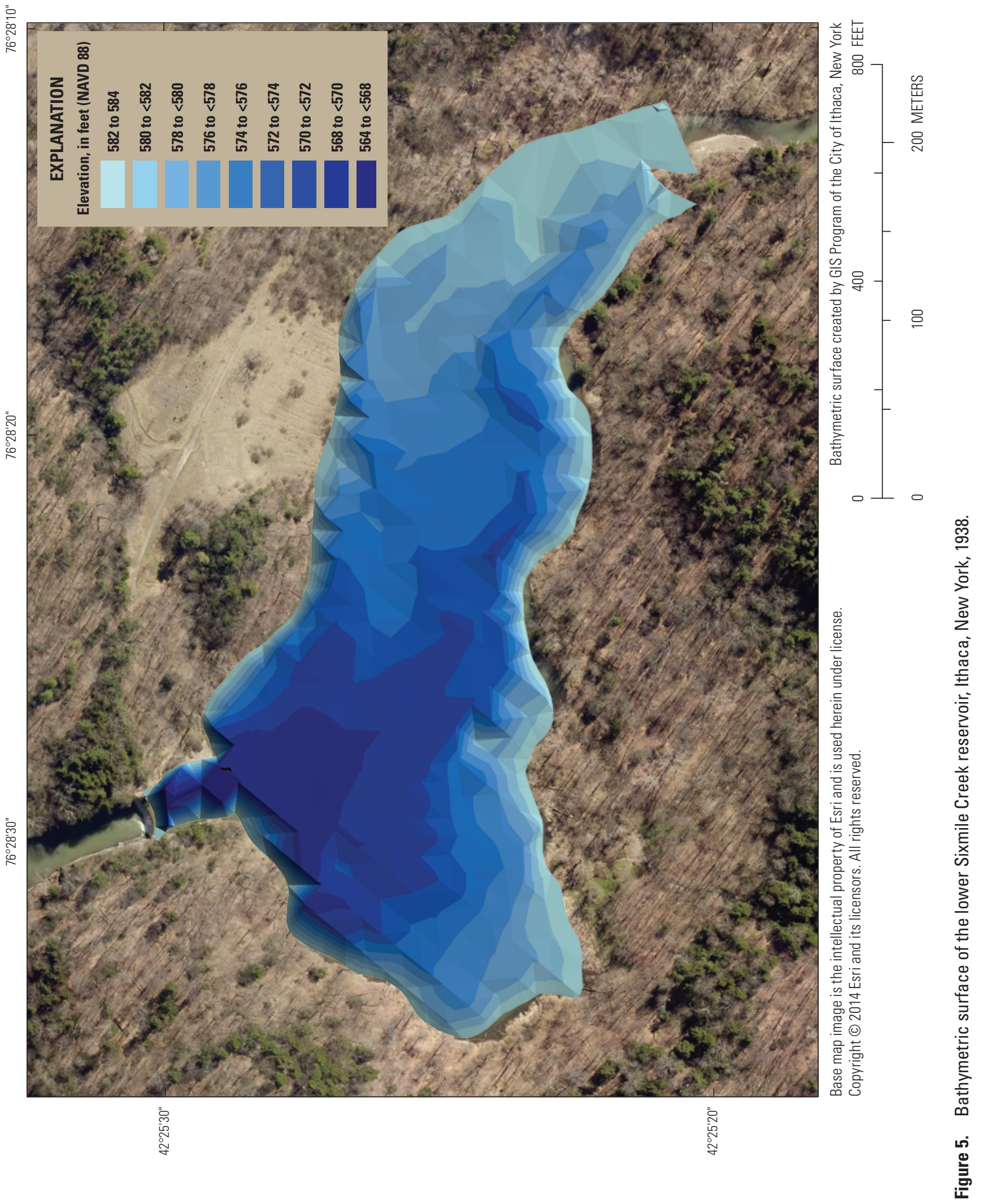


had been made, they likely would have shown the greatest rate of sedimentation between 1903-11, before the construction of the upper Sixmile Creek reservoir, which acts as a sediment trap for loads that previously were carried into and deposited in the lower Sixmile Creek reservoir.

For the 1938 and 2015 surveys, the ArcMap surfacevolume tool (Esri, 2015) was used to compute the surface area and storage capacity of the reservoir in 1-foot increments at and below $583 \mathrm{ft}$, NAVD 88 ( $583.5 \mathrm{ft}$, NGVD 29) (table 1; fig. 6). A comparison of these results, including those at the normal pool elevation of $582.5 \mathrm{ft}$, NAVD $88(583 \mathrm{ft}$, NGVD 29), indicates that at a normal pool water-surface elevation (1) the surface area decreased from 19.6 acres in 1938 to 13.9 acres in 2015 and (2) the capacity of the reservoir decreased from 152 acre-feet (acre-ft) in 1938 to 83.7 acre-ft in 2015. Based on these results, the volume of sediment that has accumulated in the reservoir between 1938 and 2015 is about 68 acre-ft. This sediment load is attributed to annual inputs from the watershed above the reservoir, as well as from a landslide that filled a large part of the reservoir along its northern edge in 1949 (see fig. 2).

No data could be found from which the surface area and total storage capacity of the reservoir at the time it was constructed in 1903 could be computed. However, the U.S. Army Corps of Engineers (1981) dam-inspection report cites a 1925 report from the City of Ithaca Engineer to the New York State Engineer and Surveyor, wherein a total capacity of 287 acre-ft and a surface area of 20 acres at the crest elevation are given. For lack of any other information or confirmation of when these values were computed, they are presumed to represent the capacity and surface area of the reservoir at the time of its completion in 1903. Based on these data, the total volume of sediment that has accumulated in the reservoir since 1903 is about 200 acre-ft.

Table 1. Surface area and storage capacity of the lower Sixmile Creek reservoir, Ithaca, New York, 1903, 1938, and 2015.

[NAVD 88, North American Vertical Datum of 1988; NGVD 29, National Geodetic Vertical Datum of 1929; --, no data]

\begin{tabular}{|c|c|c|c|c|c|c|c|}
\hline \multicolumn{2}{|c|}{$\begin{array}{l}\text { Reference elevation, } \\
\text { in feet }\end{array}$} & \multicolumn{3}{|c|}{$\begin{array}{l}\text { Surface area, } \\
\text { in acres }\end{array}$} & \multicolumn{3}{|c|}{$\begin{array}{l}\text { Storage capacity, } \\
\text { in acre-feet }\end{array}$} \\
\hline NAVD 88 & NGVD 29 & 1903 & 1938 & 2015 & 1903 & 1938 & 2015 \\
\hline 583 & 583.5 & -- & 19.7 & 13.9 & -- & 162 & 90.7 \\
\hline${ }^{1582.5}$ & ${ }^{1} 583.0$ & ${ }^{2} 20$ & 19.6 & 13.9 & ${ }^{2} 287$ & 152 & 83.7 \\
\hline 582 & 582.5 & -- & 19.0 & 13.6 & -- & 143 & 76.8 \\
\hline 581 & 581.5 & -- & 17.8 & 13.0 & -- & 124 & 63.6 \\
\hline 580 & 580.5 & -- & 16.8 & 12.0 & -- & 107 & 51.1 \\
\hline 579 & 579.5 & -- & 15.7 & 10.5 & -- & 90.9 & 39.8 \\
\hline 578 & 578.5 & -- & 14.4 & 8.69 & -- & 75.9 & 30.2 \\
\hline 577 & 577.5 & -- & 13.1 & 7.25 & -- & 62.1 & 22.3 \\
\hline 576 & 576.5 & -- & 11.8 & 6.15 & -- & 49.7 & 15.6 \\
\hline 575 & 575.5 & -- & 10.5 & 5.14 & -- & 38.5 & 9.94 \\
\hline 574 & 574.5 & -- & 9.10 & 3.13 & -- & 28.7 & 5.71 \\
\hline 573 & 573.5 & -- & 7.33 & 1.67 & -- & 20.5 & 3.36 \\
\hline 572 & 572.5 & -- & 5.91 & 1.08 & -- & 13.9 & 2.01 \\
\hline 571 & 571.5 & -- & 4.70 & 0.70 & -- & 8.63 & 1.13 \\
\hline 570 & 570.5 & -- & 3.37 & 0.36 & -- & 4.55 & 0.61 \\
\hline 569 & 569.5 & -- & 1.90 & 0.23 & -- & 1.93 & 0.31 \\
\hline 568 & 568.5 & -- & 0.88 & 0.14 & -- & 0.57 & 0.13 \\
\hline 567 & 567.5 & -- & 0.16 & 0.06 & -- & 0.12 & 0.03 \\
\hline 566 & 566.5 & -- & 0.04 & 0.00 & -- & 0.02 & 0.00 \\
\hline 565 & 565.5 & -- & 0.01 & -- & -- & 0.01 & -- \\
\hline 564 & 564.5 & -- & 0.00 & -- & -- & 0.00 & -- \\
\hline
\end{tabular}

${ }^{1}$ Normal pool water-surface elevation; that is, the elevation of the ponded water under base-flow conditions.

${ }^{2}$ From U.S. Army Corps of Engineers (1981). 


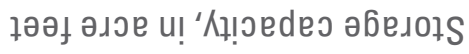

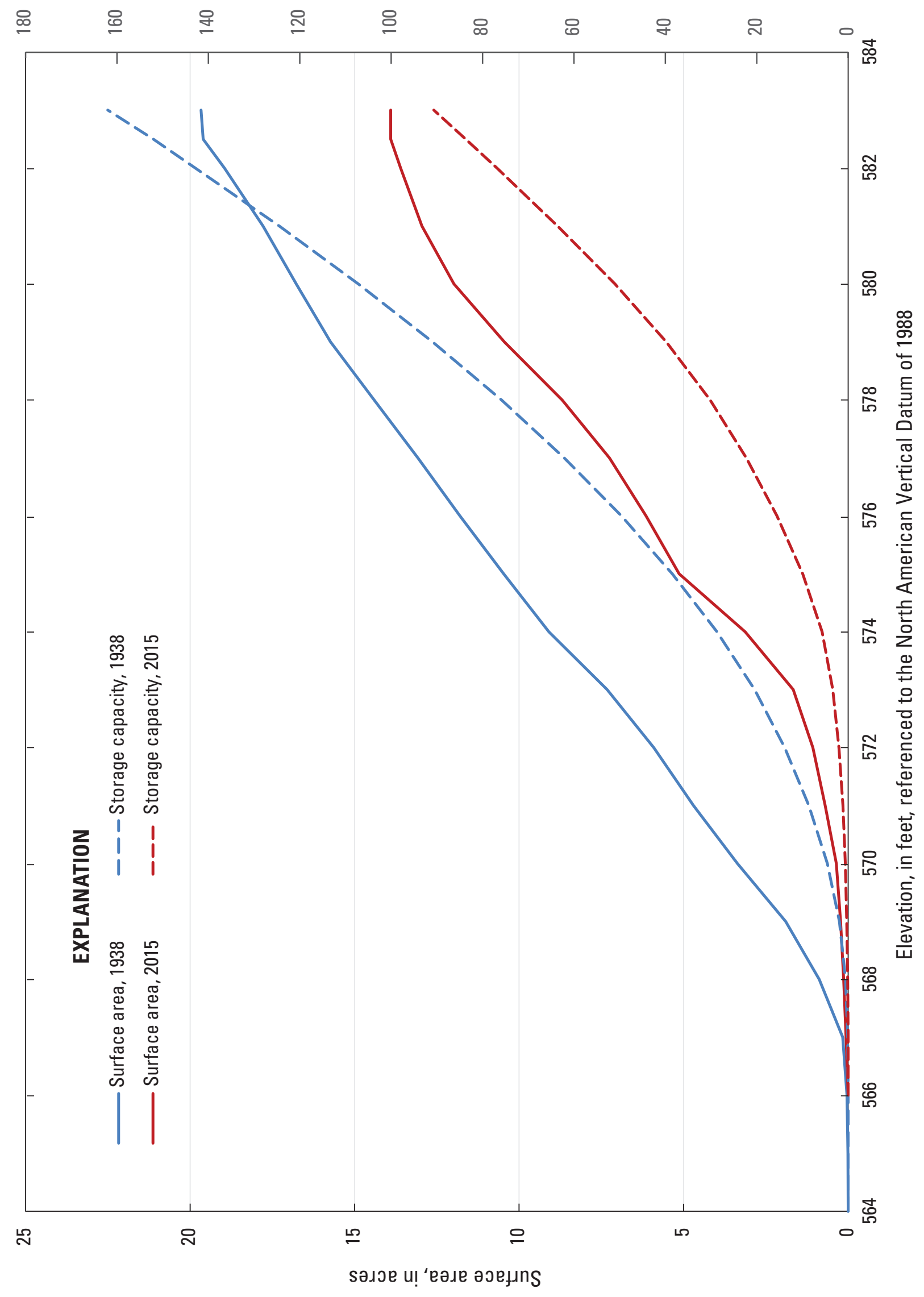




\section{Summary}

A bathymetric survey of the lower Sixmile Creek reservoir in Tompkins County, New York, was conducted by the U.S. Geological Survey, in cooperation with the City of Ithaca, New York, and the New York State Department of State, during November 2015. The usable storage capacity of the reservoir was estimated from collected data. This estimate could help city managers with decisions regarding the disposition of the 30 -foot (ft) dam that creates the reservoir and the possible use of the reservoir as a floodcontrol structure.

The U.S. Geological Survey collected bathymetric data with an acoustic Doppler current profiler. In areas where aquatic vegetation interfered with the acoustic Doppler current profiler signal, depths were manually measured. The maximum depth of the reservoir, $16.6 \mathrm{ft}$, was measured about $130 \mathrm{ft}$ upstream from the dam. Depths closer to the dam were about $13.5 \mathrm{ft}$, far shallower than the original $30-\mathrm{ft}$ depth.

City of Ithaca personnel created a bottom-elevation surface from the collected depth data. A second surface was created from depths that were manually measured during 1938. These maps and the bathymetric data from which they were created are available as a separate data release through USGS ScienceBase. Surface areas and storage capacities were computed at 1 -ft increments of elevation for each bathymetric survey. An elevation of $583 \mathrm{ft}$, National Geodetic Vertical Datum of 1929 (or $582.5 \mathrm{ft}$, North American Vertical Datum of 1988), which corresponds to the elevation of the crest of the dam and that of the reservoir's normal pool or watersurface elevation under base-flow conditions, was used as a reference elevation for these computations. The results indicate that the current storage capacity of the reservoir at its normal water-surface elevation is about 84 acre-feet and that sediment accumulated between 1938 and 2015, has decreased the reservoir's capacity by about 68 acre-feet. This sediment load is attributed to annual inputs from the watershed above the reservoir, as well as from an episodic landslide that filled a large part of the reservoir along its northern edge in 1949. Historical data from circa 1925 suggests that the original storage capacity of the reservoir was 287 acre-feet and that about 200 acre-feet of sediment has accumulated in the reservoir since its creation in 1903.

\section{References Cited}

C.T. Male Associates, 2014, Engineering assessment for Six Mile Creek dam: C.T. Male Associates, 27 p. plus appendices.

Esri, 2015, ArcGIS: Esri Web site, accessed December 1, 2015, at http://www.esri.com/software/arcgis/.
HYPACK, Inc., 2015, HYPACK hydrographic survey software, version 15.0: HYPACK, Inc., Web site, accessed November 2015 at http://www.hypack.com.

National Geodetic Survey, 2015, OPUS Online Positioning User Service: National Geodetic Survey database, accessed November 2015 at http://www.ngs.noaa.gov/OPUS/.

National Geodetic Survey, 2016, VERTCON—North American vertical datum conversion: National Geodetic Survey Web site, accessed January 2016 at http://www.ngs. noaa.gov/TOOLS/Vertcon/vertcon.html.

New York State Department of Environmental Conservation (NYS-DEC), 2016, New York State inventory of dams: NYS-DEC, Division of Water, Bureau of Flood Protection and Dam Safety [dataset available at NYS-DEC Natural Resources and Environmental Protection Maps Web page], accessed May 2, 2016, at http://www.dec.ny.gov/ pubs/103459.html.

Rydlund, P.H., Jr., and Densmore, B.K., 2012, Methods of practice and guidelines for using survey-grade global navigation satellite systems (GNSS) to establish vertical datum in the United States Geological Survey: U.S. Geological Survey Techniques and Methods, book 11, chap. D1, 102 p. with appendixes.

SonTek, 2015a, RiverSurveyor LIVE (RSL): SonTek Web page, accessed June 20, 2016, at http://www.sontek.com/ softwaredetail.php?RiverSurveyor-LIVE-RSL-34.

SonTek, 2015b, RiverSurveyor ${ }^{\circledR}$ S5 and M9: SonTek Web page, accessed June 20, 2016, at http://www.sontek.com/ productsdetail.php?RiverSurveyor-S5-M9-14.

Trimble, 2016, Trimble R8 GNSS System: Trimble Web page, accessed March 14, 2016, at http://www.trimble.com/ Survey/trimbler8gnss.aspx.

U.S. Army Corps of Engineers, 1981, Phase I inspection report, National Dam Safety Program, Sixmile Creek Dam: U.S. Army Corps of Engineers, New York District, 94 p.

U.S. Army Corps of Engineers, 2002, Engineering and design - Hydrographic surveying manual: U.S. Army Corps of Engineers EM 1110-2-1003, 510 p.

U.S. Geological Survey, 2013, Ithaca East, NY: U.S. Geological Survey US Topo 7.5-minute map, 1 sheet, scale 1:24,000.

Wernly, J.F., Zajd, H.J., Jr., and Coon, W.F., 2016, Geospatial dataset of bathymetric survey of lower Sixmile Creek reservoir, Ithaca, New York, 2015: U.S. Geological Survey data release, accessed September 2016 at http://dx.doi. org/10.5066/F7G15Z0S.

Wilson, G.L., and Richards, J.M., 2006, Procedural documentation and accuracy assessment of bathymetric maps and area/capacity tables for small reservoirs: U.S. Geological Survey Scientific Investigations Report 20065208, 24 p. 

For additional information write to:

Director, New York Water Science Center U.S. Geological Survey

30 Brown Road

Ithaca, NY 14850

Information requests:

(518) 285-5602

or visit our Web site at:

http://ny.water.usgs.gov

Publishing support by:

The Pembroke Publishing Service Center 
